\title{
Establishment of the 2nd National Reference Standard for Diphtheria toxin in Korea
}

\section{So Young Kim ${ }^{1,3}$, Jinwoong Lee ${ }^{1}$, Sol Jeon' ${ }^{1}$, Su Jung $\mathrm{An}^{1}$, In yeong Hwang ${ }^{1}$, Jae Hoon Moon², Jong Kwan Park², Taeseung Yang ${ }^{2}$, Jaewoon Son ${ }^{2}$, Daegeun Kim², Jeongwon Jang ${ }^{2}$, Seulgi Park², Eun Ah Choi ${ }^{2}$, Jin Kyu Kim², Jin Tae Hong ${ }^{3}$, Jong Won Kim ${ }^{1 *}$}

${ }^{1}$ National Institute of Food \& Drug Safety Evaluation, Ministry of Food and Drug Safety, Cheongju 28159, Republic of Korea

${ }^{2}$ GC Pharma Co LTD, Research Center, Yongin 16924, Republic of Korea

${ }^{3}$ Chungbuk University, College of Pharmacy, Cheongju 28160, Republic of Korea

\author{
Corresponding \\ Jong Won Kim, Director (Vaccines Division) \\ National Institute of Food \& Drug \\ Safety Evaluation, Ministry of Food and \\ Drug Safety, Cheongju 28159, Republic \\ of Korea \\ Phone : +82-43-719-5401 \\ Fax : +82-43-719-5400 \\ E-mail : jongwonkim@korea.kr
}

Received : January 11, 2021

Revised : March 22, 2021

Accepted : March 26, 2021

No potential conflict of interest relevant to this article was reported.

Copyright (C) 2021 Journal of Bacteriology and Virology

(C) This is an Open Access article distributed under the terms of the Creative Commons Attribution Non-Commercial License

(http://creativecommons.org/

license/by-nc/3.0/).
The reference standards perform an important role in standardization and consistent quality control of biologicals such as vaccines. The study was aimed to establish the 2nd national standard for diphtheria toxin used in diphtheria potency assay of diphtheria toxoid combined vaccines. The stocks of the first national standard established in 2007 were exhausted, and in 2019, Freeze-dried diphtheria toxin was produced in two lots, 1,962 and 1,942 vials respectively. The feasibility of manufacturing was evaluated through quality evaluation and long-term and accelerated stability tests for candidates. In order to assign the potency of candidate standards, the collaborative study was conducted with five institutions including vaccine manufacturers. The potency of the candidate standards was assigned a value of $210 \mathrm{~L}+/ \mathrm{vial}$ (95\% confidence interval- MFDSB-19-002: 208.52 221.58 L+/vial, MFDS-B-19-003: 208.63 219.61 L+/vial). It was confirmed that there was a significant difference in the basic statistics of institutions through One-way ANOVA. But when the post hoc test was conducted to verify the result of ANOVA, not much difference was shown from individual institutions as low variability. Additionally, statistical equivalence was confirmed from institutions. The candidate standard whose quality has been verified will be registered as the second national standard for diphtheria toxin.

Key Words: Bacterial vaccine, Diphtheria toxoid combined vaccine, Diphtheria toxin, National Reference Standard, Potency assay, Quality control

\section{INTRODUCTION}

제 1급 법정전염병에 속하는 디프테리아는 Corynebacterium diphtheriae 감염에 의해 발생되는 질환으로 전세계적으로 발생하며 특히 온대기후지역에서 발병률이 더 높다 $(1,2)$. 디프테리아는 대게 보균자와의 직접 접촉 또는 호흡기를 통해 전염되며, 오염된 물체에 의 해 감염이 일어나기도 한다 $(3,4)$.

백신에는 사백신, 불활화백신, 약독화백신, 재조합단백질백신 최근에는 RNA 백신까지 그 형 태는 다양하다 (5). 그 중 톡소이드백신은 세균에서 생성된 독(toxin)을 포름알데히드와 같 은 화학물질을 처리하여 독성은 제거하고 항원성은 그대로 살린 단백질 톡소이드로 제조된 다 (6). 국내에서는 1954년 예방접종 대상 감염병으로 지정되어 1958년부터 디프테리아 
톡소이드 백신을 접종하기 시작하였다 (7). 현재 디프테리아, 파상풍 및 정제 백일해 혼합백신(DTP백신)은 국가필수 기초예방접종 백신으로서, 신생아 및 영유아에 기본적으로 접종하고 있다. DTP 백신뿐만 아니라 개량 폴리오 불활성화 백신, 헤모필루스 인플루엔자 B 백신과 혼합되어 4가 백신(DTP-IPV) 및 5가 백신(DTP-IPV-Hib)이 개발되었고, 최근에는 B형간염의 유전자재조합 백신이 혼합된 6가 백신(DTP-IPV-Hib-HepB) 까지 개발되어 허가되었다 (8). 국내 디프테리아 발병률은 1985년 DTwP 백신 도입으로 크게 줄어들다가 부작용으로 인한 접종률 감소로 발생이 증가하였고, 1982년 DTaP 백신 도입 이후 발생이 현저히 줄어들게 되었으며 1988년 이후 현재까지 국내 환자 발생 보고는 없다 (9).

생물학적 시험은 화학의약품과 같이 정량적인 분석이 아닌 일반적으로 표준품 대비 함량 또는 역가를 측정하기 때문에 시험법의 표준화 가 필요하며 이에 따라 공신력 있는 표준품이 필요하다. 세계보건기구(World Health Organization, WHO)의 Expert Committee on Biological Standardization (ECBS)와 영국의 National Institute for Biological Standards and Control (NIBSC)는 국제표준품 확립 및 분양을 통해 생물학적 제제 분야의 표준화에 이바지하고 있다. 하지만 생물학적제제 표준품은 한번에 생산할 수 있는 양의 한계가 있 기 때문에 확립된 국제표준품은 전세계에 충분히 공급될 수 없으며 이에 각 나라별로 국제표준품 대비 국가표준품 또는 지역표준품을 제 조하여 사용하도록 권고하고 있다 $(10,11)$. 우리나라에서도 식품의약품안전처에서 1998년부터 생물의약품 국가표준품 개발 사업을 시 작하여 Table 1 과 같이 30 종의 생물의약품 국가표준품을 분양, 관리하고 있다.

Table 1. List of Korean National Reference Standards for biologics

\begin{tabular}{|c|c|c|c|}
\hline Code & Product name & Intended use & $\begin{array}{l}\text { Storage } \\
\text { temperature }\end{array}$ \\
\hline $01 / 001$ & Tetanus Toxin & Potency assay & $-20^{\circ} \mathrm{C}$ \\
\hline $01 / 003$ & $\begin{array}{l}\text { Interferon alpha-2a } \\
\text { (Human, rDNA-derived, for bioassay) }\end{array}$ & Potency assay & $-70^{\circ} \mathrm{C}$ \\
\hline $02 / 005$ & Bordetella Pertussis Vaccine & Potency assay & $-70^{\circ} \mathrm{C}$ \\
\hline 02/008 & Antithrombin Concentrate & Potency assay & $-20^{\circ} \mathrm{C}$ \\
\hline 03/009 & Hepatitis C Virus RNA & $\begin{array}{l}\text { Nucleic acid } \\
\text { amplification test }\end{array}$ & $-70^{\circ} \mathrm{C}$ \\
\hline 03/011 & $\begin{array}{c}\text { Interferon alpha-2a } \\
\text { (Human, rDNA-derived, for characterization) }\end{array}$ & Physicochemical assay & $-70^{\circ} \mathrm{C}$ \\
\hline 03/012 & Prekallikrein Activator & Potency assay & $-20^{\circ} \mathrm{C}$ \\
\hline 06/016 & $\begin{array}{l}\text { Bordetella Pertussis Vaccine } \\
\text { (for specific toxicity test) }\end{array}$ & Specific toxicity test & $4^{\circ} \mathrm{C}$ \\
\hline $07 / 017$ & Diphtheria Toxin & Potency assay & $-20^{\circ} \mathrm{C}$ \\
\hline $07 / 019$ & Bordetella Pertussis FHA Antiserum & Identification test & $-20^{\circ} \mathrm{C}$ \\
\hline $07 / 020$ & Bordetella Pertussis PT Antiserum & Identification test & $-20^{\circ} \mathrm{C}$ \\
\hline $07 / 021$ & Bordetella Pertussis Antiserum & Identification test & $-20^{\circ} \mathrm{C}$ \\
\hline $07 / 022$ & JE Vaccine, 2nd (Inactivated) & Potency assay & $-70^{\circ} \mathrm{C}$ \\
\hline $08 / 026$ & Anti-Hepatitis B Immunoglobulin & Potency assay & $-20^{\circ} \mathrm{C}$ \\
\hline 09/033 & Botulinum A type Antitoxin & Identification test & $-20^{\circ} \mathrm{C}$ \\
\hline 09/034 & Purified Vi Polysaccharide Typhoid Vaccine & $\begin{array}{l}\text { Content test } \\
\text { Identification test }\end{array}$ & $4^{\circ} \mathrm{C}$ \\
\hline $09 / 035$ & Blood Coagulation Factor VIII: Concentrate, 2nd & Potency assay & $-20^{\circ} \mathrm{C}$ \\
\hline $10 / 036$ & Tetanus Antitoxin & Potency assay & $-20^{\circ} \mathrm{C}$ \\
\hline $11 / 037$ & Blood Coagulation Factor IX, Concentrate & Potency assay & $-20^{\circ} \mathrm{C}$ \\
\hline $12 / 040$ & Anti-Tetanus Human Immunoglobulin & Potency assay & $-20^{\circ} \mathrm{C}$ \\
\hline $14 / 041$ & JE Vaccine, 3rd (Inactivated) & Potency assay & $-70^{\circ} \mathrm{C}$ \\
\hline $14 / 042$ & Haemophilus Influenza type B Polyribosylribitol phosphate & Potency assay & $-20^{\circ} \mathrm{C}$ \\
\hline $14 / 044$ & Pertussis Toxin & Histamine sensitization test & $-70^{\circ} \mathrm{C}$ \\
\hline $14 / 045$ & Hemorrhagic Fever with Renal Syndrome Vaccine & Potency assay & $-70^{\circ} \mathrm{C}$ \\
\hline MFDS-B-15-001 & Live Varicella Vaccine, $3 r d$ & Potency assay & $-70^{\circ} \mathrm{C}$ \\
\hline MFDS-B-15-002 & Snake Venom, 2nd & Potency assay & $-20^{\circ} \mathrm{C}$ \\
\hline MFDS-B-15-003 & Pneumococcal conjugated vaccine & Potency assay & $-20^{\circ} \mathrm{C}$ \\
\hline MFDS-B-16-001 & Filgrastim & Content assay & $4^{\circ} \mathrm{C}$ \\
\hline MFDS-B-16-002 & Cell-derived Japanese Encephalitis Vaccine (Beijing) & Potency assay & $-70^{\circ} \mathrm{C}$ \\
\hline MFDS-B-17-001 & $\begin{array}{c}\text { Cell-derived Japanese Encephalitis Vaccine (Beijing) } \\
\text { positive control serum }\end{array}$ & Potency assay & $-70^{\circ} \mathrm{C}$ \\
\hline
\end{tabular}

* Refer to the website of National Institute of Food \& Drug safety evaluation (https://www.nifds.go.kr) 
디프테리아 톡소이드 백신과 같이 백신은 건강한 사람에게 투여하는 의약품으로 품질관리가 중요하다. 백신의 일관성 및 신뢰성 있는 생 산을 위해서는 효능을 평가하는 역가시험이 중요한 지표 중에 하나이다 디프테리아 톡소이드 백신의 역가시험에는 여러 가지 방법이 있 다. 검체백신을 기니피그에 투여한 후 디프테리아 독소표준품으로 공격하여 생존율이나 홍반반응을 측정하는 독소직접공격법과 피내독 소공격법, 검체백신을 기니피그에 투여하여 얻은 혈청을 디프테리아 독소와 중화반응하고 중화된 혈청을 기니피그에 투여하여 생존율을 확인하는 독소중화법, 검체백신을 마우스에 투여 후 얻은 혈청을 독소와 중화반응을 일으킨 후 Vero 세포의 이상반응을 확인하는 중화항 체가측정법 등이 있으며, 국내 공정서인 생물학적제제 기준 및 시험방법과 세계보건기구(WHO) 및 유럽약전 등 해외공정서에서 상기 방 법들을 상세히 기술하고 있다 (12-14). 최근에는 동물실험의 $3 R$ 원칙을 위하여 부분적 in vitro 대체시험이 연구되고 있는 추세이다. 이 처럼 국내외 공정서에서 언급된 디프테리아 역가시험법 모두 디프테리아 독소 표준품이 필수적이다. 이에 디프테리아 독소 국가표준품을 2007년에 확립하여 디프테리아 톡소이드 백신의 국가출하승인 및 제조사, 수입사의 품질관리에 사용되었다. 확립된 1차 국가표준품의 재고 소진에 따라 2 차 국가표준품이 필요하게 되었으며 표준품 후보물질을 제조 후 역가 산정하기 위한 공동연구 및 장기 안정성시험을 통해 국가표준품을 확립하고자 하였다.

\section{MATERIALS AND METHODS}

\section{디프테리아 독소 후보물질의 제조}

디프테리아 독소 생산을 위하여 제조용 균주(Corynebacterium diphtheria Park Williams \#8)를 Wads Worth 배지(20 mL; In-house)에 $35 \pm 2^{\circ} \mathrm{C}, 24 \pm 4$ 시간 종균배양을 실시하고, 종균배양액을 N-Z-case 배지( 1 L; Kerry, Beloit, WI, USA)에 접종하여 $35 \pm 2^{\circ} \mathrm{C}, 24 \pm 4$ 시간 증균하였다. 종균배양액을 NZ-case 배지 50 L에 접종하여 $35 \pm 1{ }^{\circ} \mathrm{C}, 48$ 시간 배양하여 본 배양액을 확보하였다. 배양 완료된 배양 액은 4,000 rpm, 4 ${ }^{\circ}$, 30 분간 원심분리(Hanil scientific Inc., Gimpo, Korea) 여 균체와 상청액을 분리하고, 분리된 상청액은 필터 $(1.2 \mu \mathrm{m}, 0.45 \mu \mathrm{m}$ 필터, Sartorius, Goettingen, Germany)로 여과하였다. 배양 여과액에 $0.01 \mathrm{M}$ PBS 3L를 첨가하고 멤브레인 필터 (Sartorius)를 이용하여 $2 \mathrm{~L}$ 로 농축하였다. 이후 농축액에 $24.5 \%(\mathrm{w} / \mathrm{v})$ 가 되도록 황산암모늄을 첨가하고 3시간 교반 후 원심분리 $(4,000 \mathrm{rpm}, 60$ 분 $)$ 하여 상청액 회수하고 여기에 다시 포화도가 $55 \%$ 가 되도록 황산암모늄 첨가한 후 원심분리하였다. 원심분리된 침전 물을 $0.01 \mathrm{M} \mathrm{PBS}$ 에 녹여 회수한 침전물 용해액을 독소 원액으로 사용하였다. 독소 원액을 $0.22 \mu \mathrm{m}$ 필터(Sartorius)로 여과시킨 후 바 이알 당 $1 \mathrm{~mL}$ 씩 충전하여 동결건조기(SP Scientific, Stone Ridge, NY, USA)에서 동결건조 시켜 디프테리아 독소 국가표줌품 후보물질 을 최종적으로 제조하였다. 다만 동결 건조하는 용량의 한계가 있어 같은 독소 원액을 두 번에 걸쳐 동결건조과정을 수행하였기 때문에 두 로트의 후보물질은 각각 1,962, 1,942 바이알 제조되었다(제조번호 MFDS-B-19-002, MFDS-B-19-003).

\section{독소 후보물질의 품질평가}

동결건조 된 두 가지의 디프테리아 독소 후보물질은 성상, 함습도, 단백함량(Bradford법), SDS-PAGE, 응집(flocculation)시험, 순도시 험, 독소활성도 시험을 통해 품질 평가하였다.

\section{1) 성상시험}

성상은 육안으로 관찰하며, 관찰 시 백색의 동결건조물을 확인한다.

\section{2) 함습도시험}

디프테리아 독소 후보물질의 함습도 함량은 칼피셔법으로 측정하였다 (15). 제습기를 미리 가동하여 습도를 $40 \%$ 이하 조건으로 맞춰준 다. Over-Karl Fischer Volumetric (Metrohm, Filderatadt, Switzerland) 장비의 시험 조건을 $120^{\circ}$ 로 세팅한 다음 공시험 시료 3 개를 준비하여 auto-sampler에 위치시킨다. 그리고 디프테리아 독소 후보물질 3 바이알 각각의 cake를 잘게 부순 후 전자저울에서 무게를 측 정한 다음 검체를 auto-sampler에 위치시킨다. 측정한 시료의 무게를 karl-fisher 장비에 입력시킨 후 함습도를 측정한다. 함습도 산출은 검체 수분량에서 공시험 샘플의 수분 측정량을 제외시켜 계산된다.

\section{3) SDS-PAGE}

디프테리아 독소 후보물질을 환원(reducing), 비환원(non-reducing) 조건에서 $85^{\circ}$ C, 5 분간 가열하여 4 - $20 \%$ Tris-glycine 겔에 로딩 
하여 225V, 40분간 전기영동장치로 전개시켰다. 전기영동이 끝난 겔은 Commassie blue R-250 염색약에 1 시간 동안 교반하여 염색한 후 탈색액을 부어 겔이 투명해질 때까지 탈색한다. 디프테리아 독소는 $62 \mathrm{kDa}$ 위치에서 확인된다 (16).

\section{4) 응집시험(Flocculation)}

디프테리아 독소 후보물질의 Lf 함량을 측정하기위해 Ramon 응집시험을 수행하였다 (17). 생리식염수를 사용하여 디프테리아 항독소 (NIBSC 63/007)는 $100 \mathrm{IU} / \mathrm{mL}$ 로 희석하고, 검체는 $50 \mathrm{Lf} / \mathrm{mL}$ 이 되도록 희석한다. 디프테리아 항독소용액 $(100 \mathrm{IU} / \mathrm{mL})$ 과 생리식염수를 사용하여 $35 \sim 65 \mathrm{IU} / \mathrm{mL}$ 이 되도록 5단위씩 7개의 튜브에 희석한 다음 각 튜브에 검체를 $1 \mathrm{~mL}$ 씩 첨가하여 잘 혼합한다. 이 튜브들을 5 $0^{\circ} \mathrm{C}$ 항온수조에 튜브용액이 적당히 잠기도록 넣어준 다음 초시계를 작동시켜 면상침강반응을 관찰한다. 시험결과의 계산 방법은 첫 번째 와 두 번째 일어나는 튜브를 기록하고 최초 반응시간(Kf)을 기록한다.

톡소이드 함량 $(\mathrm{Lf} / \mathrm{mL})=$ 검체희석배수 $\mathrm{X}$ 반응순서에 의한 톡소이드함량 평균

\section{5) 순도시험(purity)}

순도시험은 단백량 대비 독소활성 $(\mathrm{Lf})$ 값으로 측정하였으며, 독소 활성도 $(\mathrm{Lf} / \mathrm{mL})$ 을 Bradford 단백량 측정치로 나눠 순도를 결정지었다. 다만, 단백질소 $1 \mathrm{mg}$ 당 단백질 $6.25 \mathrm{mg}$ 이므로 conversion factor로 6.25 를 곱하였다. (계산 예: $336 \mathrm{Lf} / \mathrm{mL} / 0.792252 \mathrm{mg} / \mathrm{mL} X$ $6.25 \mathrm{mg}$ Protein/mg N) 순도시험의 허용기준은 1,500 Lf/mg N 이다 (18).

\section{6) 독소활성도}

독소의 예비 역가를 측정하기 위하여 독소 활성도를 측정하였다 (19). 독소활성도의 단위인 L+는 독소의 항독소와의 중화 결합력을 나타 내는 단위로 디프테리아 항독소 표준품(17/230)을 $1 \mathrm{IU} / \mathrm{mL}$ 로 희석하고 $200,210,220,230$ 배 희석한 후보물질 독소와 중화반응 시킨 후 군당 $250 \sim 270 \mathrm{~g}$ 기니피그 3마리씩 피하 주사하여 4일째 모두 죽는 최소의 희석배수 값으로 $\mathrm{L}+$ 값을 결정하였다. 예를 들어 200 배 군에서 2 마리 살고 210 배 군에 2 마리살고, 220,230 배 군에서 3 마리 모두 죽었다면 최소 희석 배수 220 이 후보물질의 L+가 된다. 독소 활성도의 허용기준은 WHO 가이드라인 및 시험에 필요한 최소한 농도를 고려하여 내부기준(150 L+ 이상)을 마련하였다 (20).

\section{디프테리아 독소 후보물질의 공동연구}

표준품의 표시역가 설정을 위하여 공동연구를 계획하였고 in vivo 시험으로 수행하기 때문에 숙련도가 증명된 기관을 선택하기 위하여 디프테리아 관련 백신 허가 품목을 보유하고 품질검사 시험을 수행하고 있는 국내 제조사(주녹십자, 에스케이바이오사이언스(주, (쥐보령 바이오파마, (주한국백신)와 식품의약품안전처 식품 의약품안전평가원 백신검정과가 공동연구를 수행하였다. 시험 수행하기 전 5 개의 공 동연구 기관 모두 동물실험윤리위원회로부터 동물실험을 승인받았다. 공동연구 프로토콜은 항독소 표준품 $(17 / 230)$ 을 $1 \mathrm{IU} / \mathrm{mL}$ 로 희석 하고 독소를 4 개 군(희석배수 $200,210,220,230$ )으로 희석하여 항독소와 중화 반응시킨 다음 군당 3 마리의 기니피그에 피하 주사 후 생사를 확인한다. 각각의 공동연구 참여기관에 두 가지 후보물질 및 항독소 표준품을 포함한 공동연구에 사용되는 시약 등을 정해진 보관 온도 조건으로 보내졌고 공동연구에 사용되었다. 참여기관 별 각각 5 회 반복시험을 수행하고 15 개의 기초데이터 및 시험기록서를 공동 연구 주관기관(백신검정과)으로 송부하였다.

\section{공동연구 결과 데이터 및 통계분석}

5 개 참여 기관의 공동연구의 결과로 각 기관들 사이의 $L+$ 측정값에 대한 일원분산분석(One-way ANOVAS) 및 분산분석 결과에 대한 후 속검정(post hoc test)에 의한 기관 사이의 차이의 본질을 규명하고, 동등성에 대한 후속검정에 의해 여러 기관의 결과값들의 합동 (pooling)의 가능성을 검정하여 합동분산의 산출과 그로부터 합동 표준오차를 추정하여 기하평균을 설정 값으로 하고, 이에 대한 기하변 동계수를 제시하였다. 기하평균에 대한 유효숫자 개수를 결정하여 표준품의 표시역가를 최종 결정하였다.

\section{독소 후보물질의 장기 안정성 시험 연구}

식품의약품안전처의 의약품 등의 표준품안정성지침에 따라 장기 안정성시험을 수행하였다. 동결 건조된 후보물질의 보관온도 조건인 $-20^{\circ}$ 에서 $0,3,6,9,12$ 개월 안정성 시험을 통해 후보물질의 안정성을 확인하였으며, 안정성 시험항목은 성상, 함습도, 단백함량, 
SDS-PAGE, 응집시험, 독소활성도(역가)를 수행하였다(시험방법은 품질평가 시험방법 참조). 각 시험항목의 시험방법은 품질평가 시험 항목에 기술된 시험방법과 동일하며, 기준은 함습도의 경우 동결건조제제 완제의약품의 일반적인 함습도 기준을 근거로 $3 \%$ 이하로 하 였고, SDS-PAGE는 $62 \mathrm{kDa}$, 독소활성도는 $150 \mathrm{~L}+$ 이상, 단백함량 및 응집시험은 실측치로 설정하였다 $(16,18,20)$

\section{RESULTS}

\section{디프테리아 독소 후보물질의 특성분석}

동일한 디프테리아 원액으로 두 번의 동결건조를 통해 제조된 MFDS-B-19-002(Candidate 1)와 MFDS-B-19-003 (Candidate 2)로 바이알에 표지 부착하였다. 동결건조 된 두 가지 디프테리아 독소 후보물질은 성상, 함습도, 단백함량(Bradford법), SDS-PAGE, 응집시 험, 순도시험 독소활성도 시험을 수행하였으며, 그 결과 모두 허용 기준에 적합한 것을 확인하였다 (Table 2). 1 차 국가표준품에 비해 낮 은 독소활성도를 가졌지만 최소한의로 필요한 독소활성도 $(150 \mathrm{~L}+)$ 이상이기 때문에 적합한 것으로 확인하였다 (20). 동결건조는 sucrose $1 \%$ 포함된 조건에서 수행하였으며 독소 후보물질은 $1 \sim 2 \%$ 의 함습도를 나타냈다. 추가적으로 완충제 함량에 따른 함습도 변 화 연구를 수행한 결과, sucrose와 glycine 함량 증가에 따라 함습도가 감소(4\% -> $2 \%)$ 하는 경향을 확인하였다(Data not shown).

\section{디프테리아 독소 후보물질의 안정성 연구}

제조된 디프테리아 독소 2 차 국가표준품 후보물질 2종의 장기안정성 시험을 수행하였으며, 그 결과는 Table 3과 같다. 후보물질의 보관 온도 조건인 $-20^{\circ}$ 에서 $0,3,6,912$ 개월 보관하여 후보물질의 안정성을 확인하였고 12 개월 동안 역가에 유의미한 차이가 없는 것을 확인하였다. 0 개월차 안정성시험은 release 시험 결과로 갈음하였으며, 1 개 batch의 안정성시험으로 갈음하고자 하였으나 2개 batch 각각에 대한 안정성 시험이 필요하다 판단되어 6개월차부터 후보물질 각각에 대하여 안정성시험을 수행하였다.

Table 2. The results of quality test of Diphtheria toxin candidates

\begin{tabular}{|c|c|c|c|}
\hline \multirow{2}{*}{ Test Method } & \multirow{2}{*}{ Acceptance Criteria } & \multicolumn{2}{|c|}{ Result } \\
\hline & & Candidate (1) & Candidate (2) \\
\hline Appearance & White crystalline powder & Pass & Pass \\
\hline Moisture content & $\leq 3 \%^{a}$ & $2.12 \%$ & $1.96 \%$ \\
\hline Protein content (Bradford) & Measured Value & $792.3 \mu \mathrm{g} / \mathrm{mL}$ & $794.2 \mu \mathrm{g} / \mathrm{mL}$ \\
\hline SDS-PAGE & Main band: 62 kDa & Pass & Pass \\
\hline Purity & $\geq 1,500 \mathrm{Lf} / \mathrm{mg} \mathrm{N}^{\mathrm{b}}$ & $2,650 \mathrm{Lf} / \mathrm{mgN}$ & 2,394 Lf/mgN \\
\hline Flocculation & Measured Value & $336 \mathrm{Lf} / \mathrm{mL}$ & 304 Lf/mL \\
\hline Expectation Potency & $\geq 150 \mathrm{~L}+$ /vial $^{\mathrm{C}}$ & $210 \mathrm{~L}+$ & $210 \mathrm{~L}+$ \\
\hline
\end{tabular}

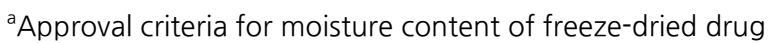

${ }^{b}$ Manual for Quality Control of Diphtheria, Tetanus and Pertussis Vaccines (2013, WHO)

'MFDS internal criteria of Diphtheria toxin

Table 3. The results of Long term stability test for Diphtheria toxin candidates

\begin{tabular}{|c|c|c|c|c|c|c|c|c|c|c|c|}
\hline \multirow{3}{*}{ Test Method } & \multirow{3}{*}{ Acceptance Criteria } & \multicolumn{10}{|c|}{ Long-term Stability (Month) } \\
\hline & & \multicolumn{5}{|c|}{ Candidate (1) } & \multicolumn{5}{|c|}{ Candidate (2) } \\
\hline & & 0 & 3 & 6 & 9 & 12 & 0 & 3 & 6 & 9 & 12 \\
\hline Appearance & White crystalline powder & pass & pass & pass & pass & pass & pass & pass & pass & pass & pass \\
\hline Moisture content & $\leq 3 \%$ & 2.12 & 1.68 & 1.89 & 2.22 & 2.39 & 1.96 & - & 1.74 & 1.79 & 2.00 \\
\hline Protein content & Measured Value & 792.3 & 794.2 & 794.6 & 808.3 & 788.9 & 764.2 & - & 781.5 & 739.8 & 795.0 \\
\hline SDS-PAGE & $62 \mathrm{kDa}$ & pass & pass & pass & pass & pass & pass & - & pass & pass & pass \\
\hline Flocculation & Measured Value & 336 & 336 & 336 & 304 & 336 & 304 & - & 344 & 336 & 336 \\
\hline Expectation Potency & $\geq 150 \mathrm{~L}+/$ vial & 210 & 210 & 210 & 210 & 210 & 210 & & 210 & 210 & 210 \\
\hline
\end{tabular}


Table 4. Results from the collaborative study comparing potency of candidates, assessed by 5 institutions

\begin{tabular}{cccccc}
\hline \multirow{2}{*}{ Standard Material } & Laboratory $^{\mathrm{a}}$ & \multicolumn{3}{c}{ Result } \\
\cline { 3 - 6 } & $\mathrm{A}$ & $\mathrm{N}^{\mathrm{b}}$ & $\mathrm{GM}^{\mathrm{c}}$ & $\mathrm{GCV}^{\mathrm{d}}(\%)$ & Inter GCV $\left.^{\mathrm{e}} \%\right)$ \\
\hline Candidate 1 & $\mathrm{1}$ & 15 & 211.2 & 2.00 & \\
(MFDS-B-19-002) & $\mathrm{B}$ & 15 & 210.0 & 0.00 & 1.61 \\
& $\mathrm{D}$ & 15 & 223.9 & 1.49 & \\
& $\mathrm{E}$ & 15 & 217.3 & 1.40 & \\
Candidate 2 & $\mathrm{A}$ & 15 & 212.6 & 2.20 & \\
(MFDS-B-19-003) & $\mathrm{B}$ & 15 & 211.3 & 1.61 & \\
& $\mathrm{C}$ & 15 & 210.7 & 0.80 & \\
& $\mathrm{D}$ & 15 & 221.3 & 1.03 & \\
& $\mathrm{E}$ & 15 & 215.9 & 1.56 & \\
\hline
\end{tabular}

aLaboratory: one of the participating laboratories, the National Center for Lot Release, Green Cross Corp. (Korea), Boryung Biopharma. Co. (Korea), SK bioscience CO. (Korea) and Korea Vaccine Co. (Korea)

${ }^{\mathrm{b}} \mathrm{N}$ : number of tests

'GM: geometric mean

${ }^{d} \mathrm{GCV}$ : geometric coefficient of variation among tests for each test institution

eInter GCV : geometric coefficient of variation among test institutions for each standard material

Table 5. Assigned Value of $2^{\text {nd }}$ national reference standard candidate of Diphtheria toxin in Korea

\begin{tabular}{ccc}
\hline Reference Standard Code & Assigned value (GMT) & 95\% Confidence Interval (CI) \\
\hline MFDS-B-19-002 & $210 \mathrm{L+} /$ vial & $208.52 \sim 221.58$ \\
MFDS-B-19-003 & $210 \mathrm{~L}+/$ vial & $208.63 \sim 219.61$ \\
\hline
\end{tabular}

\section{표준품 후보물질의 역가}

디프테리아 백신의 품질관리 시험 중 하나인 역가시험 수행에 필수적인 디프테리아 독소를 표준물질로 사용하기 위해서는 독소 후보물질 의 표시 역가가 통계적으로 적절하게 부여되어야 한다. 이에 독소의 역가를 측정하는 독소 활성도 시험방법으로 제조사 등 5 개의 기관에 서 각각 5 회씩 수행하였다. 공동연구 시험기관명 기하평균은(GMT)은 Candidate 1의 경우 Lab A 211.2, Lab B 210.0, Lab C 223.9, Lab D 217.3, Lab E 212.6으로 나타났으며, 기하변동계수(GCV)는 Lab A 2.00\%, Lab B 0.00\%, Lab C 1.49\%, Lab D 1.40\%, Lab E 2.20\%로 나타났다 (Table 4). Candidate 2는 Lab A 211.3, Lab B 210.7, Lab C 221.3, Lab D 215.9, Lab E 211.3으로 나 타났으며, 기하변동계수(GCV)는 Lab A 1.61\%, Lab B 0.80\%, Lab C 1.03\%, Lab D 1.56\%, Lab E 1.61\%로 나타났다. 독소활성 도 시험 결과에 대한 일원분산분석에서 유의한 차이가 있다고 보여(F비 $15.690>\mathrm{F}$ 임계값 2.503) 그 후속검정으로 Tukey 후속검정 하 였다. 그 결과 시험 기관들 사이의 조합에서 유의한 차이가 존재하는 것으로 확인되었지만 그 차이의 정도가 작고 기관별 변동성의 크기 가 매우 작았으며 동등성 검정에서는 기관간 쌍체비교에서 동등성이 확인되었다. 표준품 후보물질의 최종 기하평균 역가는 MFDS-B-19-002는 210 L+/vial 이며 95\% 신뢰구간은 208.52 221.58 L+/vial, MFDS-B-19-003은 210 L+/vial 이며 95\% 신뢰 구간은 208.63 219.61 L+/vial로 나타냈다 (Table 5).

\section{DISCUSSION}

디프테리아 톡소이드 관련 혼합백신의 유효성 품질관리에 중요한 디프테리아 역가시험은 현재 국내 생물학적제제 기준 및 시험방법 및 해외공정서 등에 기재되어 국내 백신 제조사와 품질검사기관에서 사용되고 있다. 디프테리아 역가시험 수행을 위해서는 디프테리아 독소 사용이 필수적이어서 식품의약품안전처에서는 2007년 일본의 Kaketsuken사에서 독소 원액을 제공받아 1,570 L+의 표시역가의 1차 디프테리아 독소 표준품으로 확립하여 분양하였으나 재고소진으로 인해 2차 국가 표준품을 제조 및 확립하여 표준품 등록 및 분양하고자 
Table 6. Comparison of $1^{\text {st }}$ national reference standard and $2^{\text {nd }}$ reference standard candidates

\begin{tabular}{ccccc}
\hline \multirow{2}{*}{ Test } & $\begin{array}{c}\text { Acceptance } \\
\text { Criteria }\end{array}$ & $\begin{array}{c}1^{\text {st }} \text { reference standard } \\
\text { (MFDS 17/007) }\end{array}$ & \multicolumn{2}{c}{ 2n reference standard candidates } \\
\cline { 4 - 5 } & $\geq 150 \mathrm{L+} / \mathrm{vial}^{* *}$ & $1,530 \mathrm{~L}+$ & MFDS-B-19-002 & MFDS-B-19-003 \\
\hline Potency & $\geq 1,500 \mathrm{Lf} / \mathrm{mg} \mathrm{N}^{*}$ & $3,233 \mathrm{Lf} / \mathrm{mg} \mathrm{N}$ & $210 \mathrm{~L}+$ & $210 \mathrm{L+}$ \\
Purity & & $2,650 \mathrm{Lf} / \mathrm{mg} \mathrm{N}$ & $2,394 \mathrm{Lf} / \mathrm{mg} \mathrm{N}$ \\
\hline
\end{tabular}

${ }^{*}$ Manual for Quality Control of Diphtheria, Tetanus and Pertussis Vaccines (2013, WHO)

${ }^{* *}$ MFDS internal criteria of Diphtheria toxin

하였다. 2 차 국가표준품 후보물질은 국내 제조사인 (주녹십자에서 동결 건조된 4,070 바이알을 제조하였고, 후보물질에 대한 품질평가 및 안정성 시험을 통해 후보물질의 타당성을 확인하였다. 품질이 검증된 후보물질의 역가산정을 위해 숙련도를 가진 국내 디프테리아 관 련 백신 제조사 등과 다기관 공동연구를 수행하였으며 백신검정과를 포함한 다섯 기관에서 L+ 역가를 산정한 결과, 기관 내 CV (\%)는 모 든 기관에서 $5 \%$ 이하로 높은 정밀성을 보였다. 하지만, 분산분석 결과에서 기관 간에 차이가 존재하는 것으로 확인되었다. 이는 기관 간 의 차이가 큰 차이가 아님에도 불구하고 기관 내 정밀성이 매우 높기 때문에 그 차이가 유의하다 확인되는 것으로 예상된다. 2 차 국가표 준품 후보물질은 기존의 1 차 국가표준품과 비교하여 역가, 순도 모두 낮은 값을 가지고 있지만 국가표준품 허용기준을 모두 만족하였다 (Table 6). 또한 설정된 표시역가를 근거로 1차 국가표준품, 2 차 국가표준품 후보물질을 이용하여 상용 디프테리아 혼합백신(녹십자티디 백신프리필드시린지 및 보령디티에이피백신)의 역가를 측정하였을 때 모두 허가 기준에 적합한 결과를 얻음으로써 1차 국가표준품과 2 차국가표준품과의 동등성 및 대체 가능성을 확인하였다. 표시역가가 결정된 디프테리아 독소 표준품은 2021년 식품의약품안전처 시험 검사발전실무위원회의 심의를 거쳐 최종 국가표준품으로 등록될 예정이며, 이후 주기적으로 안정성시험을 수행하여 표준품으로서의 품 질을 점검 및 유지하며 분양을 지속할 것이다. 국가표준품의 분양을 통해 규제기관의 국가출하승인 시험 및 제조사와 품질검사기관의 시 험에 활용하여 품질관리의 신뢰성 및 일관성을 확보할 수 있을 것이라 기대된다.

\section{ACKNOWLEDGEMENTS}

국가표준품 후보물질을 제조하고 확립하기 위해 연구에 참여해준 기관 (주)녹십자, (주보령바이오파마, 에스케이바이오사이언스(주, (주한국 백신 그리고 통계분석관련 자문해주신 숙명여자대학교 조정환 교수님 모두에 감사드립니다. 본 연구는 식품의약품안전처 연구개발비 (19202MFDS260, 20201MFDS286)로 수행되었다.

\section{REFERENCES}

1) Holmes RK, Barksdale B. Genetic analysis of tox ${ }^{+}$and tox bacteriophages of Corynebacterium diphtheria. J viro/ 1969; 3:586-98.

2) Sharma NC, Efstratiou A, Mokrousov I, Mutreja A, Das B, Ramamurthy T. Diphtheria. Nat Rev Dis Primers 2019;5:81.

3) Hadfield TL, McEvoy P, Polotsky Y, Tzinserling VA, Yakovlev AA. The pathology of diphtheria. J Infect Dis 2000; 181:S116-20.

4) Youwang $Y$, Jianming $D$, Yong $X$, Pong $Z$. Epidemiological features of an outbreak of diphtheria and its control with diphtheria toxoid immunization. Int J Epidemio/1992:21:807-11.

5) Plotkin SA. Vaccines, vaccination, and vaccinology. J Infect Dis 2003:187:1349-59.

6) Möller J, Kraner M, Sonnewald U, Sangal V, Tittlbach H, Winkler J, et al. Proteomics of diphtheria toxoid vaccines reveals multiple proteins that are immunogenic and may contribute to protection of humans against Corynebacterium diphtheria. vaccine 2019;37:3061-70.

7) Choi UY, Lee SY, Kwak GY, Ma SH, Park JS, Kim HM, et al. Immunogenicity and safety of primary and secondary DTaP booster vaccination. J Korean Med Assoc 2011:54:979-87. 
8) Kang JH, Lee HJ, Kim KH, Oh SH, Cha SH, Lee J, et al. The Immunogenicity and Safety of a Combined DTaP-IPV//Hib Vaccine Compared with Individual DTaP-IPV and Hib (PRP T) Vaccines: a Randomized Clinical Trial in South Korean Infants. J Korean Med Sci 2016:31:1383-91.

9) Korea Centers for Disease Control and Prevention. Communicable diseases surveillance yearbook, 2019. Seoul, Republic of Korea: Korea Centers for Disease Control and Prevention, 2019.

10) World Health Organization. Recommendations for the preparation, characterization and establishment of international and other biological reference standards In: Technical Report Series No 932. 2006. p.85.

11) WHO Expert Committee on Biological Standardization: WHO Technical Report Series, No. 1004, 2017. Annex 6. WHO manual for the preparation of secondary reference materials for in vitro diagnostic assays designed for infectious disease nucleic acid or antigen detection: calibration to WHO International Standards, https://www.who.int/ bloodproducts/norms/SecStandManWHO_TRS_1004_web_Annex_6.pdf.

12) MFDS Notification No. 2020-2. Ministry of Food and Drug Safety; 2020. Minimum requirements for biologics (Korea), Amended on January 9, 2020, https://mfds.go.kr/brd/m_211/view.do?seq=14424.

13) WHO Expert Committee on Biological Standardization : WHO technical report series, No. 800, 1990. Annex 2. Requirements for Diphtheria, Tetanus, Pertussis and combined vaccines, https://apps.who.int/iris/bitstream/handle/ 10665/39526/WHO_TRS_800_(part2).pdf;jsessionid=A3D1D5D827704B8C2B1F0FED75F10324? sequence=2.

14) Choi CW, Moon JH, Kim JO, Yoo SH, Kim HG, Kim JH, et al. Evaluation of Potency on Diphtheria and Tetanus Toxoid for Adult Vaccines by In Vivo Toxin Neutralization Assay Using National Reference Standards. Osong Public Health Res Perspect 2018:9:278-82.

15) Höhnemann T, Steinmann M, Schindler $S$, Hoss $M$, König S, Ota $A$, et al. Poly(Ehylene Furanoate) along Its Life-Cycle from a Polycondensation Approach to High-Performance Yarn and Its Recyclate. Materials(Basel) 2021;14:1044.

16) Lange MJ, Lyddon TD, Johnson MC. Diphtheria Toxin A-Resistant Cell Lines Enable Robust Production and Evaluation of DTA-Encoding Lentiviruses. Sci Rep 2019;9:8985.

17) Coombes L, Rigsby P, Sesardic D, Stickings $P$. Collaborative study for the calibration of a replacement International Standard for diphtheria toxoid for use in flocculation test. Biologicals 2016:44:556-66.

18) WHO Expert Committee on Biological Standardization. Recommendations to assure the quality, safety and efficacy of diphtheria vaccines (adsorbed). In: Sixty-third report. Technical Report Series no 980 Annex 4. Geneva: World Health Organization; 2014. p.211e69.

19) Barile MF, Kolb RW, Pittman M. United States standard diphtheria toxin for the Schick text and the erythema potency assay for the Schick text dose. Infect Immun 1971:4:295-306.

20) World Health Organization. Chapter II: Testing for Diphtheria vaccine. In Manual for Quality control of Diphtheria, Tetanus and Pertussis Vaccines; World Health Organization: Geneva, Switzerland: 2013. p.21-97. 